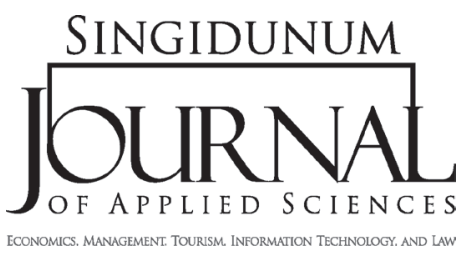

\section{ROLE OF SOCIAL MEDIA IN SERBIA}

\section{Ivan Bauer*}

Singidunum University, Faculty of Economics, Finance and Administration

43 Bulevar Vojvode Mišića Street, Belgrade, Serbia

\begin{abstract}
:
The era of one-way marketing communication is slowly coming to an end and traditional marketing techniques are being replaced by modern techniques which have two-way communication with incorporated target groups. This happens most frequently with explicit approval given by customers. Traditional-to-digital media shift was mainly driven by technological breakthroughs which have made communication possible "anywhere". "Big screen" (television) has been replaced by "little screen" (mobile phone), while newspapers, radio, libraries, cinemas and tête-à-tête communication have been replaced by computers, Internet, and, eventually, the social media. Marketers' primary task has always been to be in the same place as their consumers, which is why they have been forced to adjust their techniques to modern times and circumstances. A newly arisen marketing technique, which stands out particularly for its present and expected future importance, is Social Media marketing.

Marketers around the world have recognized Social Media marketing as an important part of their marketing communication portfolio. Although marketing experts in small markets recognize the importance of new technologies and marketing techniques, they are facing severe problems in their implementation, most frequently, due to inferior technical capabilities, as well as different cultural and educational barriers.

The aim of this paper is to highlight the global importance of the aforementioned technique, as well as to assess the position of Serbia in terms of its implementation at the present time, and where we can expect it to be tomorrow. Obtaining answers to these questions creates foundation and space for further future analyses, together with the rise in implementation of marketing techniques in social media in Serbia. Also, it provides more information about understanding and implementation, as well as about different perceptions of the importance of implementation and about various perspectives concerning marketing techniques in social media in Serbia. In order to accomplish those objectives, diverse research methods have been used - from observation and case study method to interviews and surveys.
\end{abstract}

SINGIDUNUM JOURNAL 2012, 9 (2): 1-8

ISSN 2217-8090

UDK 32.019.5(497.11)

Original paper/Originalni naučni rad

\section{Key words:}

Social Media marketing, traditional marketing, integrated marketing communication, social media, perspectives.

\section{INTRODUCTION}

The main characteristic of the XXI century is the technological revolution in the field of communication driven by breakthrough in the areas of mobile telecommunication and broadband in-
ternet.These telecommunication accomplishments have made new communication techniques possible among people, all the time and in every place. Unfortunately, new possibilities have brought new challenges, as well. New means of communication which, almost immediately, have become very popular and 
widely accepted, are recognized by customers as an integral part of their personal space. Therefore, the task marketers face, with the aim of reaching their target groups, is very delicate and should be approached with great attention. On the one hand, marketers have attained new, different possibilities for communicating with their customers, which can not be ignored. On the other hand, customers' "protective" attitude towards their personal space and their clear wish (and need) to have (absolute) control over their space, makes this communication very difficult for marketers in the XXI century. The only acceptable solution (for both parties) is reaching consensus among marketers and customers about what is acceptable and what is not, and creating "communication partnership", which will bring satisfaction and benefits to both parties.

\section{THEORETICAL BACKGROUND}

Marketing "micro-space" looks more and more like a chaotic system in which modern customers get bombarded with unacceptable quantity of commercial messages.As a result, two new phenomena have emerged- marketing overload and ad avoidance. Marketing overload is related to the fact that our brains are not capable of processing such amount of (commercial) information we are receiving every day. As a logical consequence, consumers are getting more and more keen on finding new ways to avoid all kind of commercial information they get exposed to throughout the day. Therefore, traditional ways (traditional marketing) of addressing the public are doomed to extinction or, at least, to slow "death". Emergence of social media has given marketers the opportunity to connect with their customers in a new, more sincere and open way. Problem that marketers/companies have to face in social media is that information flow in a new surrounding cannot be controlled. In order to solve this problem, marketers must change their perception of the world and their way of thinking, since in the modern world brands are not what companies think they are, but what people say they are! And people (customers) are going to communicate their opinion urbi et orbi - on a social web ${ }^{1}$, of course. The choice not to participate in these conversations is simply unacceptable since it will give boost to the "enemies" of the brand ("brand detractors" in the social media language) and make them look

1 social web = social media. like they are right. Taking part in such conversations, on the other hand, not only gives marketers benefits of redirecting conversations in the desired direction, but also demonstrates company's interest in customers' opinions, which customers know how to appreciate. If we put the famous statement given by Sam Walton, Wal-Mart founder: "If you have a question, go to the store. Your customers have the answer." (Evans, 2008, p.260) into the modern context, by paraphrasing it, we get the very essence of social media communication and its importance: "If you have a question, go to the social web. Your customers have the answer and they have been discussing it (for quite some time)!"

The fact that the social media popularity growth has a very steep upward curve is more or less known even to a marketing layman. What is less known and less expected, is that relative participation of "senior" population $(35+)$ grows, while relative participation of "juniors" declines, according to The Nielsen Company's recent study (2009). This data makes other information coming from the same study more than logical:

- social media is the fastest growing internet segment,

- social media has become more popular internet service than e-mail,

- social web is approaching $75 \%$ of internet users that use social media,

- social media represents more than $10 \%$ of the overall internet traffic,

- quantity of time spent on social media is growing at incredible pace - for example, in December 2007. - December 2008. period, growth pace reached 63\% (for Facebook that number is much greater $-566 \%$ !).

The customers' attitude towards companies / brands' participation in social media is almost unanimous:

- $93 \%$ of customers expect companies/brands to, at least, participate in social media,

- $85 \%$ of customers feel that their presence should be in a form of constant interaction with customers, and the most improtant

- 56\% of customers say that companies can expect to be rewarded for this interaction by creating a stronger relationship among customers and brands.

However, social media have its shortcomings. Unlike traditional media where communication is 
controlled by marketers, social media interaction is uncontrollable. Social web has been built on conversations, but those discussions, according to Evans (2008, p.132), "do not belong to marketers, but instead belong to someone else." That someone else is neither "Big brother", nor some defined person/ group - simply, the social web does not belong to anyone particular and it belongs to everyone. The message that marketer creates stops belonging to him the minute it leaves his hands because in social media, unlike traditional media, content is continiously recreated (redone) beyond anybody's control. What companies can control is experience customers have had with their porducts/services, as well as companies' behaviour on the social web. Essence replaces form - messages are less important, relationship with customers and customers' experience are much more important! Therefore, it is not easy to sell (and it should not be sold) the idea of using social media as a marketing tool just because they are new and "trendy". The use of social web for marketing purposes represents a challenge for marketers, considering numerous possibilities, as well as risks that social media presence (or absence) generates. What calls for caution of marketers not very inclined to risk is:

- unknown and hostile environment,

- absence of reliable metrics, and

- still more or less predictable results of traditional media marketing campaigns.

Even though "magic formula", which will forever unite marketers and social media, has still not been discovered, more and more companies are working on it very thoroughly. More than three -fourths of Fortune 1000 companies use some kind of social media marketing, and their number, as well as activity volume grow every day.

In order to make social media marketing programs planning much easier, it is recommended to split social media channels into functional groups. This can give us an extra benefit of having "ready containers" prepared to catch new social media channels and content formats as they emerge. A very convenient way of dividing social media into groups is the proposition given by Robert Scoble, called the
"Starfish model" (Evans, 2008). Namely,this model (see Figure 1) puts a participant (customer) at the center of undergoing "social activities",where he is about to make a conversion as a result of interaction with, or exposure to the surrounding social media ecosystem, which is divided into three main categories:

- Social platforms,

- Social content, and

- Social interactions.

Social platforms include social networks (Face-
Figure 1. Starfish model of social media

Source: Evans, D. (2008) book, MySpace, LinkedIn etc.), white-label social networks (e-communities, forums...) and wikis (Wikipedia and similar collaborative, collective platforms that drive consensus around ideas).

Everything created and shared by social media users (no matter if they are companies or customers), and then put into circulation on the social web, represents social content. Photos, blogs, microblogs (Twitter), audio and video podcast, ratings and reviews, all belong to this group.

Social interactions make sense of the growing quantity of social information which is threatening to overload consumers in one moment. In order to prevent that, social media users have social interactions at their disposal, which helps them organize (social) information they want to gather.

\section{THE CURRENT SITUATION IN SERBIA}

In order to assess current state of social media marketing in Serbia and (try to) predict its future development, a research study has been conducted. 
As a research method, the author used independently developed questionnaire. When choosing participating companies, the author's main focus was on their leadership and/or management leadership skills. Selected companies were divided in two groups: production companies and companies providing diverse services. The division, which served as a vehicle for statisical analysis, has attempted to determine whether or not there has been a statistical diference in using social media marketing techniques between these two groups of companies. $\chi^{2}$ test has been a logical choice for this type of analysis:

$$
\chi^{2}=\sum \frac{\left(f_{o}-f_{t}\right)^{2}}{f_{t}}
$$

where $f_{o}$ represents obesrved frequencies ${ }^{2}$, and $f_{t}$ represents theoretical frequencies ${ }^{3}$. If summary of the equation is greater than or equal to 0.05 ( $p$-value $\geq$ 0.05 ), then we can conclude that there is no statistically significant difference between observed and theoretical frequencies. Vice versa, if summary is less than 0.05 ( $p$-value $<0.05)$, we can say that statistically significant difference exists.

The most popular social media in Serbia, among Serbian leaders, is Facebook, followed by YouTube and LinkedIn- the result which has been expected because of Facebooks' extreme popularity among general public (currently, there are around 2,5 million Facebook accounts in Serbia). The above mentioned statistics is consistent with findings of the two comprehensive studies previously done in Serbia by Ipsos Strategic Marketing (2011) and Universal McCann (2010). Though it might be more logical to see Twitter, SlideShare or blogs on this list (instead of YouTube), it is obvious that specific social media's local popularity is affected by their global popularity ${ }^{4}$, but also by different cultural, social and other factors.

The first important indicator of the Serbian social media marketing situation, in comparison to global tendencies analized in this paper, has been one of the most significant indicators of "social" behaviour - following active participation in the discussions of interest for the company. The result is more than encouraging - more than $70 \%$ of Serbian important companies use this technique, mostly by

2 frequencies which are the result of the research.

3 expected frequencies.

4 in specific groups. following/participating in discussions on Facebook, Twitter and LinkedIn. Among the interviewed companies, $43 \%$ of them have answered that they plan to spread their presence across social media in the future. Most often they have mentioned Twitter and blogs as the next social media marketing tools they plan to incorporate in their integrated marketing programme. Obviously, Serbian companies are giving very strong consideration to entering diverse social media marketing fields, following, in that way, footsteps of their colleagues from the developed countries.

If we analize particular social media marketing techniques ${ }^{5}$, we can see that, as expected, Facebook marketing is the most popular and relatively speaking, widely accepted marketing technique among Serbian leading companies. Almost two thirds of the interviewed companies have Facebook marketing in their marketing portfolios, which can be characterized as a very good result, especially when we take into consideration the fact ${ }^{6}$ that marketing presence of Serbian companies in social media is not very impressive. One of the interesting questions posed to the interviewed parties refers to the ways in which they grade results of their Facebook marketing campaigns. The results have shown almost equal dispersion of the given answers : bad, satisfactory, good, very good.This indicates that Serbian marketers, like their colleagues from the developed countries, have problems with insufficient and improperly verified metrics, which corresponds very well with global tendencies of trying to establish adequate metrics so that social media marketing results can be properly measured and assessed. The two most popular Facebook marketing techniques are, as expected, fan clubs and Facebook groups which are used ${ }^{7}$ by more than half of the interviewed companies. This represents a very good and encouraging result for Serbian marketers, especially because it is in accordance with the results of Ipsos Strategic Marketing (2011) study which shows that $51 \%$ of Serbian Facebook users join fan clubs/groups. Another extremely popular Facebook marketing technique, used by participants in this survey, is the creation of branded Facebook applications/games, which is one of the most "social" marketing techniques among Facebook marketing tools. More than $40 \%$ of the interviewed companies have used this marketing tech-

5 we'll do that only for those which are not completely insignificant in Serbia.

6 the result of this study, as well.

7 as a marketing technique. 
nique, just to mention some of the examples: "It's time for gifts" ("Vreme je za poklone") by Telecom Serbia, "Leasing calculator" by VB Leasing Serbia, "Loan settled and money in the pocket" ("Dug sit i pare na broju") by Societe General Bank Serbia, etc.

Twitter is no longer the "privilege" of the marketeers from the developed countries. Almost 40\% of the interviewed Serbian companies follow their competitors on Twitter. This data tells us that modern marketing techniques in developing countries, in this case Serbia, are converging towards global trends in the area. Aprroximately $83 \%$ of companies participating in the survey said that they use Twitter $-52 \%$ of them do it passively, by observing, and $31 \%$ actively, by tweeting. $13 \%$ of the interviewed companies tweet on regular basis, which signifies that they post tweets at least once a day. Some 43\% of company tweets are often answered by audience, which means that companies' target group recognizes the value of the tweets. Retweets are, as expected, more rare - "only" $29 \%$ of company tweets get retweeted. Even though this may not look as such a good result, it actually is, because retweeting is not something that tweeters like doing. When they retweet something, it means that they find it very valuable and/or their source respectful.

Almost half of the companies (43,5\%), taking part in the interview and being prepared for this paper, have presented their companies on Wikipedia, which is not a very bad result for a country postitioned not so high on the global telecommunication technology development list. Nevertheless, it remains inexplicable why others have not done the same thing when it is a very simple task which can do a lot for the promotion of the company and its values in social media, and in the virtual world, in general.

Even though LinkedIn assumes a very high position on the preffered social media list among Serbian leaders, they tend to use it more as a vehicle for self-promotion than as a social media marketing tool. That conclusion can be drawn from the following results:

- only $10 \%$ of the interviewed companies have recruited candidates for vacant positions in their companies through means provided by LinkedIn,

- whereas $29 \%$ of Serbian leaders take active participation in LinkedIn's “Answers" section trying to improve their professional image.
One of the determinants of "social behaivour" is a degree of integration of social media marketing techniques. Serbian marketers, participants in the study, do integrate their social media marketing techniques $^{8}$ in majority of the cases, $77 \%$ of them, to be precise. Information that might be very helpful in assessing the attitude of Serbian marketers towards social media marketing is the percentage of companies having social media marketing as an integral part of their overall marketing budget, and, even more helpful, percentage of companies planning to increase investments in social media marketing in the following year (see Table 1). The data gathered in the survey tells us that almost half of the interviewed companies have social media marketing budget, while majority (almost two thirds) of the companies even plan to increase their social media marketing budget spendings in the years to come.

\begin{tabular}{ccc}
\hline \multirow{2}{*}{ budget } & for this year & $\begin{array}{c}\text { increase in the years } \\
\text { to come }\end{array}$ \\
\cline { 2 - 3 } & $47,83 \%$ & $60,87 \%$ \\
\hline $\begin{array}{c}\text { importance for } \\
\text { marketing mix }\end{array}$ & useful & extremely important \\
\cline { 2 - 3 } & $60,87 \%$ & $34,78 \%$ \\
\hline
\end{tabular}

Table 1: Importance of Social Media marketing
Another information which is very important for assessing the attitude towards social media marketing among Serbian marketers comes as an answer to a simple question: "Do you consider social media marketing: extremely important, useful or irrelevant part of marketing mix?" Results showed that Serbian leaders see social media marketing as a very important part of marketing mix (see Table 1).

Statistically significant difference between results from the survey gathered from production companies and companies that provide services has been notified in a small amount of cases. The most notable example is the use of Facebook fan club and/ or group as a social media marketing tool. The conclusion arising from this analysis is that production companies are more dedicated to creating fan club pages and/or groups on Facebook than companies that provide services. Further analysis has shown that production companies put more effort into updating content on regular basis in their fan clubs/

8 which shouldn't be confused with the integration of social media marketing and traditional marketing techniques. 
groups, as well. This result has come as a big surprise since creation and updating of Facebook group/fan club does not represent a difficult task - maybe it's time consuming, but, even that, not too much, and it certainly is very easy to implement and, what is more important ${ }^{9}$, it is free. On the other hand, this social media marketing technique is very efficient in reaching companies' target group - therefore, it should be present in any companies' marketing portfolio.

Gathering all the information and summarizing it in the final conclusion regarding the current Serbian social media marketing situation, it can be said that the presence of Serbian companies in social media has an upward-oriented curve, with the present state characterized as "presence in majority of cases". As a trend that has been observed, it has been notified that volume of presence in social media is not big, which reminds us most of the "testing" phase of social media presence, which was to determine its marketing potential.

\section{CONCLUSION: PERSPECTIVES}

As a form of conclusion regarding the current state of social media marketing and its perspectives in Serbia, we can paraphrase the words of professor Christine Moorman from the Duke University's Fuqua School of Business, putting them into the Serbian context: Serbian "marketers think social media marketing is here to stay and will play an increasingly important role in their work in acquiring and retaining customers in the future." (Porterfield, 2010) Increasingly growing number of social media users in Serbia, especially the number of Facebook users, has contributed to the growing level of perception of the importance of social media as a marketing tool among the leading companies in Serbia. The survey analysis has determined that Serbian marketers focus on the most popular social media - Facebook, which represents the only logical outcome when we take into consideration the fact that Facebook is, by far, the most popular social media in Serbia, in terms of number of accounts (almost 2.5 million) and relatively in comparison to other social media. The fact that the majority of the interviewed Serbian marketers use simpler social media marketing techniques tells us that social media marketing in Serbia is, at the moment, dominant in the phase of testing. However, encouraging results that have shown major commitment to increase social media marketing budgets in the years to come, promise not only a better future for social media marketing practitioners in

9 especially during financial crisis. the nearest future, but also further growth of importance of social media marketing for overall marketing programs in the Serbian companies.

In order to promote the continuing growth of importance of social media and social media marketing techniques, all interested parties - the government, marketers and social media users must give their contribution. The government is to fullfil its promises regarding the increase of broadband internet penetration level (Vlada Republike Srbije, 2009), and take more proactive role in the increase of nation's computer literacy. Serbian companies, on their behalf, should invest larger portion of their marketing funds in education of marketing departments, which would lead to the increased use of more sophisticated social media marketing techniques and in the overall use of these techniques, in general. By actively participating in the two aforementioned processess and by using feedback mechanism,social media users may give a significant contribution to:

- further development of social media in Serbia,

- social media behaviour rules defining, and

- overall improvement of social media marketing communication.

Only proactive approach by all interested parties can guarantee forecasted bright future for the social media marketing in Serbia.

\section{REFERENCES}

Bass, C.B. (2008) Social networking for newbies. Incentive. 182 (4), 30-31.

Bernoff, J. (2009) Be more than an ad, get in the conversation. Marketing research [online]. Available from: http://www.marketingpower.com/ResourceLibrary/ Publications/MarketingNews/2009/43/4/ViewPoint_ Bernoff.pdf [accessed 16 January 2012].

Cooper, B. (2009) Is social media worth your marketing dollars? [online]. Available from: http://enterpreneur. venturebeat.com/2009/09/03/is-social-media-worthyour-marketing-dollars/ [accessed 11 January 2012].

Durwin, M. (2008) How being a social network butterfly can help you land a job and improve your career [online]. Available from: http://www.mdurwin. com/2008/12/how-being-a-social-network-butterflycan-help-you-land-a-job-and-improve-your-career/ [accessed 19 December 2011].

Evans, D. (2008) Social media marketing: an hour a day. Indianapolis, Ind. : Wiley.

VanBoskirk, S., et al. (2009) US Interactive Marketing Forecast By Industry, 2009 To 2014. Cambridge, MA: 
Forrester Research [online]. Available from: http:// www.forrester.com/home\#/US+Interactive+Marketin g+Forecast+By+Industry+2009+To+2014/quickscan//E-RES55668 [accessed 4 March 2012].

Hampp, A. (2009) At century 21, social media is the new TV. Advertising Age [online]. Available from: http:// adage.com/article/cmo-strategy/century-21-real-estate-social-media-tv/136325/ [accessed 17 February 2012].

International Telecommunication Union (2011) Measuring the information society. Geneva: International Telecommunication Union [online]. Available from: http://www.itu.int/net/pressoffice/backgrounders/general/pdf/5.pdf [accessed 21 February 2012].

International Telecommunication Union (2010) The world in 2010: ICT facts and figures. Geneva: International Telecommunication Union [online]. Available from: http://www.itu.int/ITU-D/ict/facts/2011/material/ICTFactsFigures2010.pdf [accessed 3 February 2012].

Ipsos Strategic Marketing (2011) New media usage among youth [online]. Available form: http://www.irex.rs/ attachments/article/145/youth2011-english.pdf [accessed 1 March 2012].

Janković, M., et al. (2009) Pregled tržišta telekomunikacija u Srbiji za 2008. godinu. Beograd: Republička agencija za telekomunikacije RATEL [online]. Available from: http://www.ratel.rs/editor_files/File/Pregled_trzista_2008.pdf [accessed 12 April 2012]. (in Serbian)

Janković, M., et al. (2010) Pregled tržišta telekomunikacija u Srbiji u 2009. godini. Beograd: Republička agencija za telekomunikacije RATEL [online]. Available from: http://ratel.rs/upload/documents/Pregled_trzista/ Ratel\%20Pregled\%20trzista\%202009.pdf [accessed 3 April 2012]. (in Serbian)

Kotler, P., Armstrong, G. (2006) Principles of marketing. Upper Saddle River, N.J. : Pearson Prentice Hall.

MarketingSherpa (2010) Marketing Sherpa 2010 Social media marketing benchmark report. Warren, Rhode Island: Marketing Sherpa Inc. [online]. Available from: http://www.sherpastore.com/SocialMediaMkt2010. html [accessed 2 April 2012].

Martin, T. (2009) Social media is meant for conversation, not 'marketing'. Advertising Age. 80 (6), 11.

Owyang, J., et al. (2009) Social Media Playtime Is Over: Despite The Recession, More Than 50\% Of Marketers Will Pursue Social Applications. Cambridge, Massachusetts : Forrester Research Inc. [online]. Available from: http://www.forrester.com/rb/Research/social_ media_playtime_is_over/q/id/47665/t/2 [accessed 8 February 2012].

Porterfield, A. (2010) 3 new studies prove social media marketing growth. Poway, California : Social Media Examiner [online]. Available from: http://www.so- cialmediaexaminer.com/3-new-studies-prove-socialmedia-marketing-growth/ [accessed 4 February 2012].

Radulović, J. (2010) Izveštaj o radu Republičke agencije za telekomunikacije za period od 2005. do 2010. godine. Beograd : Republička agencija za telekomunikacije RATEL [online]. Available from: http://www. ratel.rs/upload/documents/Konferencije/RATEL\%20 konferencija\%2018.5.2010..pdf [accessed 21 December 2011]. (in Serbian)

Schulz, D., et al. (1994) The New Marketing Paradigm: Integrated Marketing Communications. Lincolnwood, NTC: Business books.

Schwab, K. (2009) The global competitiveness report 20092010. Geneva:World Economic Forum [online]. Available from: https://members.weforum.org/pdf/GCR09/ GCR20092010fullreport.pdf [accessed 12 December 2011].

Strategic Marketing Research (2008) Mediji i nove tehnologije među mladima u Srbiji [online]. Available from: http://xa.yimg.com/kq/groups/20918497/180311448/ name/MC-YouthMedia-2008.pdf [accessed 11 March 2012]. (in Serbian)

The Nielsen Company (2009) Global faces and networked places: A Nielsen report on social networking's new global footprint [online]. Available from: http://blog.nielsen.com/nielsenwire/wp-content/ uploads/2009/03/nielsen_globalfaces_mar09.pdf [accessed 15 January 2012].

Universal McCann (2010) Wave.5: The socialization of brands: The social media tracker - 2010 [online]. Available from: http://www.scribd.com/doc/39391023/ Social-Media-Wave-5-OCT2010-Universal-McCann [accessed 5 April 2012].

Vlada Republike Srbije (2009) Strategija razvoja širokopojasnog pristupa u Republici Srbiji do 2012. godine. Beograd: Narodna skupština Republike Srbije [online]. Available from: http://www.ratel.rs/upload/editor_files/File/Strategija\%20i\%20akcioni\%20plan\%20 razvoj\%20sirokopojasnog\%20pristupa.pdf [accessed 1 December 2011 ]. (in Serbian)

Vlada Republike Srbije (2010) Strategija razvoja informacionog društva u Republici Srbiji do 2020. godine. Beograd: Narodna skupština Republike Srbije [online]. Available from: http://www.ratel.rs/upload/ documents/razno/Strategija\%20razvoja\%20informacionog\%20drustva.pdf [accessed 1 December 2011]. (in Serbian)

Weber, L. (2009) Marketing to the Social Web: How Digital Customer Communities Build Your Business. Hoboken, N.J. : Wiley.

Zarrella, D. (2010) The social media marketing book. Sebastopol, Canada : O'Reilly. 


\section{ULOGA DRUŠTVENIH MEDIJA U SRBIJI}

\section{Rezime:}

Vreme jednosmernih marketing komunikacija polako prolazi i tehnike tradicionalnog marketinga zamenjuju moderne tehnike koje imaju inkorporiranu dvosmernu komunikaciju sa ciljnom grupom, najčešće uz izričitu dozvolu sagovornika. Tom pomeranju od tradicionanih ka digitalnim medijima umnogome su doprineli i tehnološki prodori koji su omogućili komunikaciju ljudima bilo gde da se nalaze. Veliki ekran (televiziju) zamenio je mali (mobilni telefon), a novine, radio, biblioteke, bioskope i tĕt-a-tĕt komunikaciju zamenili su kompjuteri, internet i na kraju društveni mediji. Zadatak marketara uvek je bio da se nalaze tamo gde i njihovi potrošači, te su tako oni bili prinuđeni da svoje tehnike prilagođavaju novim vremenima i okolnostima. Novonastala marketinška tehnika koja se izdvaja, po svom sadašnjem i (očekivanom) budućem značaju, je marketing u društvenim medijima.

Marketing u društvenim medijima sve više biva prepoznat od strane marketara širom planete kao vrlo važan deo portfolija tehnika marketing komunikacija. Mada i marketing lideri na manjim tržištima prepoznaju značaj novih tehnologija i marketinških tehnika, oni se suočavaju sa problemima u njihovoj implementaciji, najčešće zbog lošijih tehničkih mogućnosti, kao i zbog prisustva različitih kulturnih i obrazovnih barijera.

Ovaj rad pokušava da ukaže na globalni značaj ove tehnike i da istraži gde se Srbija nalazi u njenoj primeni danas, a gde možemo da očekujemo da će se nalaziti sutra. Dobijanje odgovora na ova pitanja stvara osnov i otvara prostor za dalje analize u budućnosti, kako bude rasla primena tehnika marketinga u društvenim medijima kod nas, ali i daje sliku o razumevanju, primeni, sagledavanju značaja primene i perspektivama tehnika marketingana u društvenim medijima u Srbiji. Za ostvarenje postavljenih ciljeva korišćeni su različiti istraživački metodi - od posmatranja i metode studije slučaja do ankete i intervjua.
Ključne reči:

marketing u društvenim medijima, tradicionalni marketing, integrisane marketing komunikacije, društveni mediji, perspektive. 